\title{
Additional Records of the American Elephantfish Callorhinchus callorynchus (Chondrichthyes, Holocephali, Chimaeriformes) in Southeastern Brazil
}

\author{
Salvatore Siciliano1,2 (D), Ana Rita 0. Palmeira-Nunes ${ }^{3}\left(\mathbb{C}^{\circ}\right.$, Getulio Rincon ${ }^{4}$ (D), \\ Jorge Luiz Silva Nunes ${ }^{3}\left(\mathbb{D}\right.$, Sérgio C. Moreira ${ }^{2,5}{ }^{\circledR}$, Márcio L. V. Barbosa-Filho ${ }^{6}$ \\ ${ }^{1}$ Laboratório de Biodiversidade, Instituto Oswaldo Cruz/Fiocruz, Rio de Janeiro, RJ, Brazil \\ ${ }^{2}$ Grupo de Estudos de Mamíferos Marinhos da Região dos Lagos (GEMM-Lagos), Araruama, RJ, Brazil \\ ${ }^{3}$ Universidade Federal do Maranhão (UFMA), Laboratório de Organismos Aquáticos, Departamento de Oceanografia e \\ Limnologia, São Luís, MA, Brazil \\ ${ }^{4}$ Universidade Federal do Maranhão (UFMA), Curso de Engenharia de Pesca, Pinheiro, MA, Brazil \\ ${ }_{5}^{5}$ Setor de Mamíferos, Departamento de Vertebrados, Museu Nacional/UFRJ, Rio de Janeiro, RJ, Brazil \\ ${ }^{6}$ Departamento de Ciências Biológicas, Programa de Pós-graduação em Etnobiologia e Conservação da Natureza, Universidade \\ Federal Rural de Pernambuco (UFRuPE), Campus Dois Irmãos, Recife, PE, Brazil \\ Email: gemmlagos@gmail.com
}

How to cite this paper: Siciliano, S., Palmeira-Nunes, A.R.O., Rincon, G., Nunes, J.L.S., Moreira, S.C. and Barbosa-Filho, M.L.V. (2020) Additional Records of the American Elephantfish Callorhinchus callorynchus (Chondrichthyes, Holocephali, Chimaeriformes) in Southeastern Brazil. Natural Resources, 11, 439-445.

https://doi.org/10.4236/nr.2020.1110026

Received: July 1, 2020

Accepted: October 18, 2020

Published: October 21, 2020

Copyright $\odot 2020$ by author(s) and Scientific Research Publishing Inc. This work is licensed under the Creative Commons Attribution International License (CC BY 4.0).

http://creativecommons.org/licenses/by/4.0/

\begin{abstract}
Chimaeras, fish in the order Chimaeriformes, are among the rarest and least studied fish in the class Chondrichthyes (cartilaginous fish). Previous records have indicated that a species of chimaera known as the elephantfish, or cockfish, Callorhinchus callorynchus, may be found in marine waters off southeastern Brazil, as far north as the state of São Paulo. Here we report that C. callorynchus, caught with bottom gillnet, was found in an urban fish market in the city of Rio de Janeiro $\left(\sim 23^{\circ} \mathrm{S}\right)$. This and other records from a variety of places call into question the distribution limits of the American elephantfish in the southwestern Atlantic Ocean and whether, at least seasonally, this species may often be found as far north as the state of Rio de Janeiro. Because of scientific and conservation interests in the poorly known Chimaeriformes, we recommend long-term monitoring of the fish catch in ports along the southern Brazilian coast, to better understand the natural history of the intriguing chimeras.
\end{abstract}

\section{Keywords}

Callorhinchus Callorynchus, American Elephantfish, Holocephali, Chimaera, Bycatch, Southwest Atlantic Ocean 


\section{Introduction}

Chimaeras (Order Chimaeriformes) are a group of poorly known, often strange-looking fish (known as rabbitfish, ghost sharks and elephantfish) that tend to live in deep waters [1]. This order is now getting a growing number of studies, with 22 new species that have been described in the past 25 years [2] [3]. They are recognized by the fusion between the upper jaw and the neurocranium, the anterior extension of the ethmoid region, and the branchial arches that are also more anterior, beneath the cranium [4]. Today, chimaeras include 51 described species in six genera (Callorhinchus, Harriotta, Rhinochimaera, Neoharriotta, Chimaera, Hydrolagus) and three families (Callorhinchidae, Chimaeridae, Rhinochimaeridae) [2] [5]. In Brazil, all three families and four genera (Callorhinchus, Harriotta, Rhinochimaera, Hydrolagus) are known to occur [1]. Typically, records of these chimaeras are accidental and come from deep water fishing. Thus, chimaeras natural history is poorly known and understanding the sustainability of this taxonomic group as a target for fishing is challenging [1].

The American elephantfish was first reported from the Brazilian state of São Paulo [6]. Thus, it was assumed that the elephantfish distribution included the vague "southern Brazil" [7], in the southwestern Atlantic, as far north as São Paulo $\left(24^{\circ} \mathrm{S}\right)$ [8]. Occasional records were reported from near Rio de Janeiro [9] [10] [11] and from the southern Brazilian state of Rio Grande do Sul [12] [13].

\section{Methods}

We conducted regular visits to fishing unions and landing ports in Rio de Janeiro state, including twice a month visits to the urban Recreio dos Bandeirantes fish market, for an evaluation of the diversity of elasmobranchs landed under Project "Elasmobrânquios como ferramentas bioindicadoras de contaminação por metais no Sudeste Brasileiro: Impactos na saúde pública e no contexto socioambiental de populações vulneráveis locais" since March 2019. On site, interviews with key-informants and collection of selected species of elasmobranchs were conducted. In addition, literature review, media news and other open sources, were searched for records of chimaeras. We searched for "Callorhinchus callorynchus" + "American elephantfish (and/or peixe-elefante in Portuguese)" + "Holocephali" + "chimaera" (and/or quimeras) + "bycatch" + "southwest Atlantic Ocean" (and/or Atlântico Sul) in all major sources of media in Brazil including Google, YouTube, Facebook, G1, Globo.com, and O Dia.

\section{Results}

Here we report on a juvenile female elephantfish that was caught in a bottom-gillnet (55 mm mesh size) on February 14, 2020 and was retrieved from the Recreio dos Bandeirantes fishmarket in the city of Rio de Janeiro. The fish, approximately $30 \mathrm{~cm}$ long, was caught in coastal waters, $\sim 2 \mathrm{~km}$ from shore (Figure 1, Figure 2). An additional observation of this species was one caught near Maricá just north of Rio de Janeiro, on April 22, 2014 in a gillnet set less than 2 km 


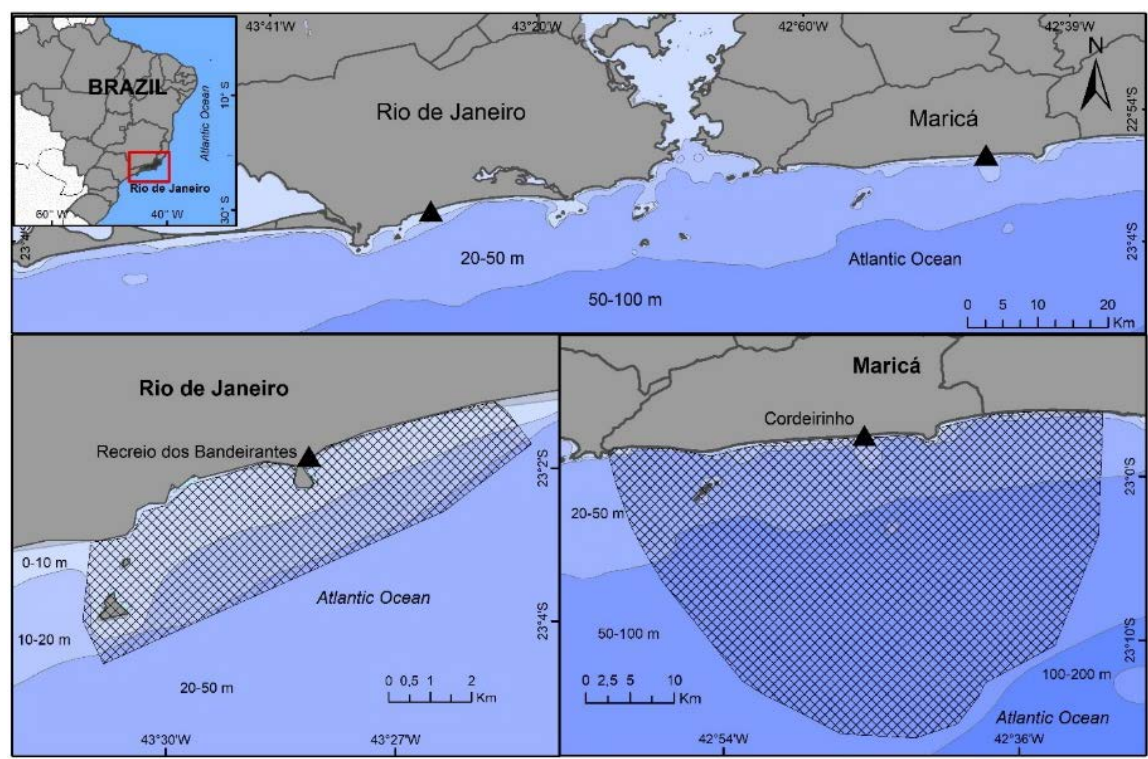

Figure 1. Map detailing the locations of the two recent captures of the American Elephantfish (Callorhinchus callorynchus) in coastal waters near the city of Rio de Janeiro, Brazil, including "Recreio dos Bandeirantes; 23.0307 ${ }^{\circ}$ S; $43.4688^{\circ} \mathrm{W}$ ” on 14 Feb. 2020 and "Maricá; $22.9585^{\circ} \mathrm{S}, 42.7568^{\circ} \mathrm{W}$ " on April 22, 2014. Locations represent the extremes of Rio de Janeiro megalopolis.

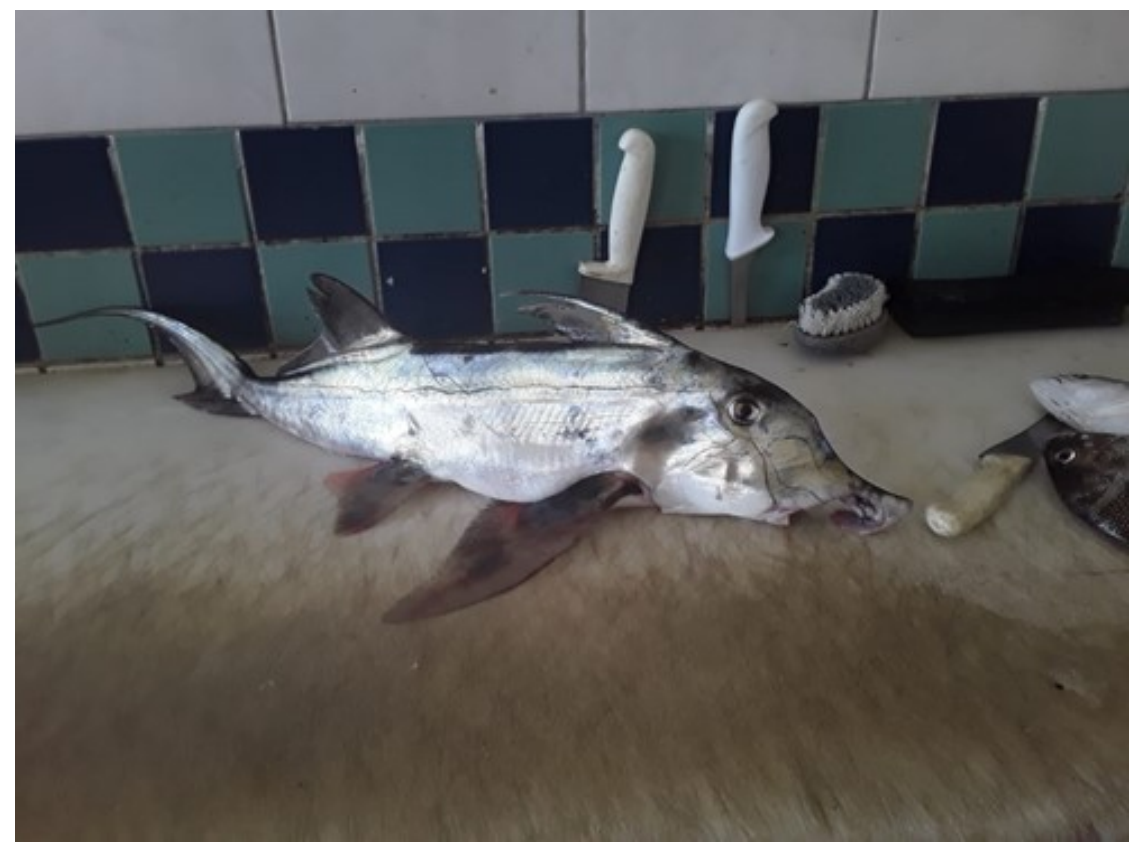

Figure 2. Photograph of the American Elephantfish (Callorhinchus callorynchus) from the fishmarket in Recreio dos Bandeirantes, Rio de Janeiro, Brazil. More dorsal view showing facial details. Note the very large pectoral fin and the dorsal spine.

from shore. Interestingly, in both cases (Recreio and Maricá), the fishes were soon eaten after being caught. These scattered records raised the question of the true distribution of the American elephantfish in the southwestern Atlantic Ocean. 


\section{Material Examined}

Callorhinchus callorynchus (Linnaeus, 1758)

New record. BRAZIL 11 우, Rio de Janeiro state, Rio de Janeiro, Recreio dos Bandeirantes; $23.0307^{\circ} \mathrm{S} ; 43.4688^{\circ} \mathrm{W}$; caught at approx. depth $30 \mathrm{~m} ; 14$ Feb. 2020; approx. $30 \mathrm{~cm}$ long; caught by fisher J. F. do Nascimento and reported to S. C. Moreira col. • 1; Rio de Janeiro state, Maricá; $22.9585^{\circ} \mathrm{S}, 42.7568^{\circ} \mathrm{W}$; caught at approx. depth $40 \mathrm{~m}$; approx. $30 \mathrm{~cm}$ long; 22 Apr 2014; reported by open source:

http://g1.globo.com/rj/regiao-dos-lagos/noticia/2014/04/raro-no-brasil-peixe-ele fante-e-fisgado-em-marica-no-rj.html.

Identification. The family Callorhinchidae is distinct from the other chimaeras due to its long rostrum in the shape of a plow, in which a cartilaginous rod or shaft supports the dorsal surface, and with the distal extremity end in the structure that resembles the plow. It also has a fusiform body, heterocercal tail (i.e., lobes unequal in size), and a large, cartilaginous, anal fin [14]. This family has only one genus with three species: Callorhinchus milii Bory de St. Vincent, 1823 from New Zealand and Australia, C. capensis Dumeril, 1865 from South Africa, and C. callorynchus (Linnaeus, 1758), from southern South America [5] [15]. These three species look similar, and they are identified by frontal tentacles in the males, or egg cases [4]. The American elephantfish, $C$. callorynchus, is a neritic fish (from $10-115 \mathrm{~m}$ depth), ranging from around $23^{\circ} \mathrm{S}$ in the Atlantic Ocean (state of Rio de Janeiro, in Brazil) to $1^{\circ} 33^{\prime} S$ in the Pacific Ocean [9] [16] [17] [18]. The presence of very large pectoral fins and one dorsal spine is diagnostic: https://www.fishbase.se/Summary/SpeciesSummary.php?id=8399\&lang=english and https://shark-references.com/species/view/Callorhinchus-callorynchus and https://shark-references.com/species/view/Callorhinchus-callorynchus.

\section{Discussion}

Recent observations of artisanally landed elasmobranchs along several ports in Rio de Janeiro [19] [20] do not cite chimaeras in their extensive lists. In fact, [19] surveyed from 2003 to 2005 the Recreio dos Bandeirantes fish market and observed 27 species of sharks and rays, not reporting on any chimaera. This agrees with the fisher (Mr. J. F. do Nascimento) who mentioned that it was the first time that such a conspicuous fish as the American elephantfish was caught in the area.

The recovery of the American elephantfish in bycatch of net fishing off the coast of the city of Rio de Janeiro (Figure 1) that is clearly identified as $C$. callorynchus (Figure 2, Figure 3), along with previous reports nearby (Rio de Janeiro, [9] and Macaé, [10]) suggests that this species may be a common, bottom-feeding species at these latitudes. Indeed, [10] comments that $C$. callorynchus is known in the region of Macaé as "cação-borboleta" ("butterfly shark"). The authors mentioned that it is usually caught at night in gillnets and is sold as "cação" meat in local markets. Accordingly, [10] informs that the 


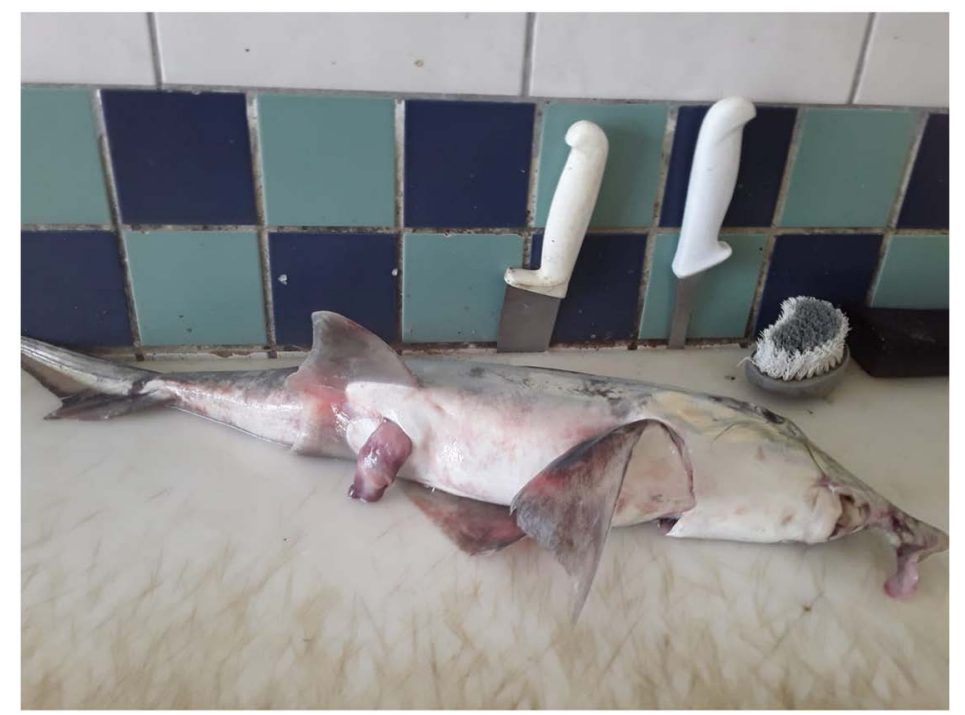

Figure 3. The same specimen in a slightly ventral view, in which the female has a cloacal prolapse. Courtesy of Mr. J. F. do Nascimento.

American elephantfish seems to be a regular, albeit uncommon, inhabitant of the region of Macaé, thus representing a range extension of c. $300 \mathrm{~km}$ northeast from the supposed northern limit of distribution of the species in the Western Atlantic Ocean.

Perhaps fishing has become more intensive, explaining why these fish have been caught more recently. Observations were performed in summer and early autumn (February and April) which may suggest some seasonality of occurrence of C. callorynchus in SE Brazil.

We strongly recommend long-term monitoring of the local fisheries as a tool to monitor and gain better understanding of local chimaera abundance and population patterns along the SE Brazilian coast. Why there are no more reported landings of this species in local fish markets is a matter of speculation. As such, we suggest that notifications be placed at the local fisheries markets, reporting on landings and explaining that these fish should not be consumed because of the potential for heavy-metals ingestion and other complex chemicals that are likely to accumulate in the tissues of this species [21]. If these fish are not consumed, then researchers may be notified that they have been caught which would be extremely helpful for a long-term monitoring program. Thus, the potential exists for better understanding the biology of a locally unusual, and poorly known species of an ancient lineage of fascinating fish, the American elephantfish.

\section{Acknowledgements}

We thank the fisher Mr. Jailson Francisco do Nascimento for providing information on the specimen caught of Recreio dos Bandeirantes. This is a contribution under "Programa Fiocruz de Fomento à Inovação (INOVA): Elasmobrânquios como ferramentas bioindicadoras de contaminação por metais no Sudeste 
Brasileiro: Impactos na saúde pública e no contexto socioambiental de populações vulneráveis locais (VPPIS-004-FIO-18)." S. Siciliano is supported by CNPq (Produtividade em Pesquisa: 306076/2019-5) and INOVA Fiocruz. The text was translated by James J. Roper, Ph.D.

\section{Authors' Contributions}

SS, GR, MLVB-F, JLSN and AROP-N wrote and reviewed the manuscript; GR, MLVB-F, JLSN and AROP-N confirmed species identification and revised the literature, SCM collected material in the field, analyzed data, prepared the map, and wrote the manuscript.

\section{Conflicts of Interest}

The authors declare no conflicts of interest regarding the publication of this paper.

\section{References}

[1] Rincon, G., Mazzoleni, R.C., Palmeira, A.R.O. and Lessa, R. (2017) Deep-Water Sharks, Rays, and Chimaeras of Brazil. In: Rodrigues-Filho, L.F.S. and Sales, J.B.L., Ed., Chondrichthyes-Multidisciplinary Approach, InTech, Rijeka, 83-112. https://doi.org/10.5772/intechopen.69471

[2] Ebert, D.A., Bigman, J.S. and Lawson, J.M. (2017) Biodiversity, Life History and Conservation of Northeastern Pacific Chondrichthyans. In: Larson, S. and Lowry, D., Eds., Northeast Pacific Shark Biology, Research and Conservation Part A, Elsevier, Amsterdam, 9-78. https://doi.org/10.1016/bs.amb.2017.07.001

[3] Lasso-Alcalá, O.M., Tavares, R., Baldwin, C., Robertson, R., Miloslavich, P. and Quintero, E. (2018) New Records of the Longnose Caribbean Chimera Neoharriotta carri (Holocephali, Chimaeriformes) in the Caribbean Sea. Abstract Book Sharks International Conference UFPB, João Pessoa, 3-8 June 2018, 246.

[4] Didier, D.A., Kemper, J.M. and Ebert, D.A. (2012) Phylogeny, Biology, and Classification of Extant Holocephalans. In: Carrier, J.C., Musick, J.A. and Heithaus, M.R., Ed., Biology of Sharks and Their Relatives, CRC Press, Boca Raton, 97-122. https://doi.org/10.1201/b11867-6

[5] Nelson, J.S., Grande, T.C. and Wilson, M.V. (2016) Fishes of the World. 5th Edition, John Wiley \& Sons, New Jersey. https://doi.org/10.1002/9781119174844

[6] Miranda-Ribeiro, A. (1928) Callorhynchus callorhynchus L. Boletim do Museu Nacional Rio de Janeiro, 4, 47-48.

[7] Dagit, D.D., Chiaramonte, G.E., Romero, M., Di Giácomo, E. and Acuña E (2007) Callorhynchus callorynchus. The IUCN Red List of Threatened Species 2007: e.T63107A133966405. https://www.iucnredlist.org/species/63107/12606367

[8] López, H.L., San Román, N.A. and Di Giácomo, E.E. (2000) On the South Atlantic distribution of Callorhinchus callorhynchus (Holocephali: Callorhynchidae). Journal of Applied Ichthyology, 16, 39. https://doi.org/10.1046/j.1439-0426.2000.00142.x

[9] Moreira Jr., W., Gomes, U.L. and Marques, A.R. (1993) Record of the Seven-Gill Shark Heptranchias perlo (Bonnaterre, 1788) and the American Elephant fish Callorhynchus callorhynchus (Linnaeus, 1758) (Pisces, Chondrichthyes) on the Coast of Rio de Janeiro State, Brazil. Registro do “Tubarão-de-Sete-Guelras" Heptranchias 
perlo (Bonnaterre, 1788) e do "Peixe-Elefante" Callorhynchus callorhynchus (Linnaeus, 1758) (Pisces, Chondrichthyes) no litoral do estado do Rio de Janeiro, Brasil. Acta Biologica Leopoldensia, 15, 145-150.

[10] Di Dario, F., Petry, A.C., Mincarone, M.M., Pereira, M.M.S. and Santos, R.M. (2011) New Records of Coastal Fishes in the Northern Rio de Janeiro State, Brazil, with Comments on the Biogeography of the South-Western Atlantic Ocean. Journal of Fish Biology, 79, 546-555. https://doi.org/10.1016/B978-85-352-7735-7.50015-6

[11] Di Dario, F., Tosin, L.F. and Mincarone, M.M. (2017) Marine Coastal Fishes of Bacia de Campos. In: Lima, S.O.F., Ed., Atlas de sensibilidade ambiental ao óleo: Caracterização ambiental regional da Bacia de Campos, Atlântico Sudoeste, Elsevier, Rio de Janeiro, 113-126. https://doi.org/10.1016/B978-85-352-7735-7.50015-6

[12] Seeliger, U., Odebrecht, C. and Castello, J.P. (1998) The Coastal and Marine Ecosystems of Extreme Southern Brazil. In: Seeliger, E., Asmus, M., et al., Os ecossistemas costeiro e marinho do extremo sul do Brasil, Ecoscientia, Rio Grande, $326 \mathrm{p}$.

[13] Gowert, Y. and Franco, M.C.O. (2019) Occurrence of a Couple of Callorhinchus callorynchus (Linnaeus 1758) off Southern Brazil. Boletín de la Sociedad Zoológica del Uruguay, 28, 92-94. https://doi.org/10.26462/28.2.6

[14] Didier, D.A. (2004) Phylogeny and Classification of Extant Holocephali. In: Carrier, J.C., Musick, J.A. and Heithaus, M.R., Ed., Biology of Sharks and Their Relatives. CRC Press, Boca Raton, 4, 115-138. https://doi.org/10.1201/9780203491317.ch4

[15] Weigmann, S. (2016) Annotated Checklist of the Living Sharks, Batoids and Chimaeras (Chondrichthyes) of the World, with a Focus on Biogeographical Diversity. Journal of Fish Biology, 88, 837-1037. https://doi.org/10.1111/jfb.12874

[16] Figueiredo, J.L. (1977) Manual de peixes marinhos do Sudeste do Brasil: introdução. Cações, raias e quimeras. Museu de Zoologia da Universidade de São Paulo, São Paulo. https://doi.org/10.5962/bhl.title.109986

[17] Sielfeld, W. and Vargas. M. (1999) Review of Marine Fish Zoogeography of Chilean Patagonia ( $42^{\circ}-57^{\circ}$ S). Scientia Marina, 63, 451-463.

[18] Cousseau, M.B. and Perrotta, R.G. (2013) Peces marinos de Argentina: Biología, distribución, pesca. 4th Edition, Instituto Nacional de Investigación y Desarrollo Pesquero, Mar del Plata.

[19] Silva Jr., L.C., Andrade, A.C. and Vianna, M. (2008) Characterization of a Small-Scale Fishery in an Area of Ecological Relevance for Elasmobranchs, at Recreio dos Bandeirantes, Rio de Janeiro State. Arquivos de Ciências do Mar, 41, 47-57.

[20] Araujo, N., et al. (2020) Artisanally Landed Elasmobranchs along the Coast of Rio de Janeiro, Brazil. Boletim do Laboratório de Hidrobiologia, 30, 33-53. http://www.periodicoseletronicos.ufma.br/index.php/blabohidro/article/view/12448

[21] López, S.A., Abarca, N., Concha, F. and Meléndez, R. (2014) Heavy Metal Concentrations in Two Important Fishes Caught in Artisanal Fisheries of Southeastern Pacific Waters. International Journal of Agricultural Policy and Research, 2, 414-420. https://doi.org/10.15739/IJAPR.014 